\title{
Modeling and Simulation of Relocation of a Production in SIMPRO-Q Web Based Educational Environment
}

\author{
http://dx.doi.org/10.3991/ijac.v5i1.1878 \\ L. Lengyel ${ }^{1}$, K.Zgodavova $^{2}$ and P. Bober ${ }^{2}$ \\ ${ }^{1}$ Faurecia Leather Kosice s.r.o. Slovakia \\ ${ }^{2}$ Technical University of Kosice, Slovakia
}

\begin{abstract}
- the aim of this paper is to show the how to get new knowledge and skills through solving production relocation situations in a continuously changing global environment. The used methods model and simulate the related risks, using web based learning environment of Quality Management Role Play Simulation (SIMPRO-Q). The presented methods are applicable also in engineering education. During simulations, the role-players make both quantitative and qualitative decisions regarding management of critical situations during production relocation. Experiences from relocation production project in industry are discussed at the end of the paper.
\end{abstract}

Index Terms-failure analysis, modeling, production relocation, project quality management, simulation.

\section{INTRODUCTION}

Relocation or the transfer (also known as 'off-shoring' or 'delocalization') of production activities by multinational companies from one country to another has become an important issue in industrial relations across Europe [1]. Transitions also occur when the production operation undergoes a shift, which may be due, for example, to start-up operations or product changes. Product quality often suffers during such transition periods [2].

Each production relocationinvolve also risks that are becoming more pronounced with increasing complexity of the production, and their anticipation and effective management presents a principal element of successful project management. Proper risk identification, analysis and management can assist the project manager to act against both known and unanticipated risks on projects of all kinds [3]. Correspondingly, any relocation project entails also concerns of the interested parties about the change and, hence, the need to motivate them. Failure to perform effective risk management can cause projects to exceed budget, fall behind schedule, miss critical performance targets, or exhibit any combination of these troubles [3].

Our literature survey showed that there are organizations focusing solely on relocating productions (such as e.g. Flatworld [4]), though we have found only very few papers that were scientifically investigating the issue of mitigating risks at relocating productions, and were mostly applying the Failure Mode Effect Analysis (FMEA) method. One of the most frequently quoted authors in this field is T. A. Carbone. To have effective methods for identification and modeling, analyzing, evaluating and simulation a project risk, with tools to overcome the change associated concerns is crucial for the project manager to mitigate against both anticipated and unanticipated risks of projects of all kinds. Modeling and simulation are disciplines for developing a level of understanding of the interaction of the parts of a system, and of the system as a whole [5]. Simulation of actions of people as representatives of either entire organizations or parts thereof by playing roles is being successfully used in research, teaching and in designing socio-technical systems for several decades [6], [7], [8].

The aim of this paper is to facilitate new approaches that would enable successfully resolve the production relocation issues. The paper is based on up to date knowledge of teaching Industrial Engineering and Quality Engineering and Management at universities, and also on the knowledge and experience of the authors in education using the Quality Management System Role Play Simulation (SIMPRO-Q) at various Higher Education Institutions (HEI) and organizations in a number of European countries.

The paper presents risk mitigation and motivation methods and tools for utilizing modeling and simulation using Project Quality Management System Role Play Simulation (PT-SIMPRO-Q) educational tool, for analysis of possible project failures and their effects - through Project Failure Mode Effect Analysis (P-FMEA), for management of both anticipated and unforeseeable project risks in accordance with ISO 31000:2010 [9] and the project quality management in conformity with ISO 10006:2003 [10].

This contribution is primarily intended for teachers and students participating in Quality Management System, New Product Development and Project Management courses. It will be useful also to professionals working in teams specializing in relocation of a production from one country to another one.

\section{PRINCIPLES AND CONCEPTS OF THE PRODUCTION RELOCATION PROJECTS}

The production relocation principles and concepts are based on the premise that proper identification of risks, their modeling, analyzing and assessing, as well as effective project quality management and targeted education can be of help at alleviating both anticipated and un-anticipated risks at all types of projects. 
"Production" is defined here as the process of producing and result of the target-oriented activities of individuals or organizations, i.e. production processes and products.

Production relocation usually occurs when an organization intends to increase business operations profitability assuming that they would do better in a new environment. The following changes are considered: need to change processes (quality, productivity, effectiveness), to change the product (new, updated quality requirements of the customer), as well as changes in the entrepreneurial environment. When relocating production, basic elements of the new business and cultural environment are carefully considered. The new environment is analyzed in detail as to the differences identified against the existing one.

Possible differences should be as well considered as significant project success factors:

- Differences in production processes;

- Differences in project products;

- Differences in the business, working and cultural environment.

Various reasons come into consideration when moving production, but in general it is:

a) Relocation to similar environment with minimum changes in processes and products.

b) Relocation to similar environment where changes in processes are needed.

c) Relocation to similar environment where changes in products are needed.

d) Relocation to similar environment where changes in both - processes and products are needed.

e) Relocation to significantly different environment where minimal changes to processes and products are needed.

f) Relocation to significantly different environment where changes to processes are needed.

g) Relocation to significantly different environment where changes to products are needed.

h) Relocation to significantly different environment where changes to processes and products are needed.

Each of the above cases has its particularities, but in this paper, the example that was modeled, belongs to situation d).

For successfully relocating a production, it is necessary to identify, analyze and assess the risks and these findings should be considered in the project quality management processes.

The concept of production relocation modeling and simulating utilizes the project quality management model according to ISO 10006:2011, the risk management model conforms to ISO 31000:2010, where the FMEA tool is customized for the project, and for the SIMPRO-Q educational tool.

\section{A. Project Quality Management}

At the base of project quality management are processes covered by ISO 10006:2010. The project is defined as a unique process, consisting of a set of coordinated and controlled activities with start and finish dates, undertaken to achieve an objective conforming to specific requirements, including the constraints of time, cost and resources. The project management includes: planning, organizing, monitoring, controlling and reporting of all aspects of a project and the motivation specifying what is necessary in order to meet the objective(s) of the project. Project processes are those processes that are necessary for managing the project as well as those that are necessary to get the project's product. It may relate to one or several production units and the product/s may be tangible or intangible. The project organization is usually temporary and is established for the lifetime of the project. The project life cycle breaks down to the following stages: conceptual work, development, realization and completion, with the possibility of their management. In our case there are 13 project quality management sub-processes, and the process product is the manufacturing of car components.

\section{B. Risk Management}

For the purpose of this paper, risk identification is the process of finding, recognizing and describing risks. Risk analysis is a process to understand the nature of risk and to determine the level of risk, that is - the magnitude of a risk or combination of risks expressed in terms of the combination of consequences and their likelihood. Risk analysis provides the basis for risk evaluation and decisions about risk treatment. Risk evaluation is the process of comparing the results of risk analysis with risk criteria to determine whether the risk and/or its magnitude are acceptable or tolerable (ISO 31000:2010).

The risk management tool used in this paper is the Failure Mode Effect Analysis (FMEA).

The FMEA technique dates back to the United States military procedure MIL-P-1629:1949. FMEA presents team-based analysis of the possibility of occurrence of risks in the proposal under consideration, evaluation of the risk and adoption of the measures ensuring improvements in quality [11]. Pritchard [12] first identified the FMEA technique as an advanced format capable of capturing project risks.

For the Project Failure Mode Effect Analysis (PTFMEA), detection techniques or methods are defined as, "the ability to detect the risk event with enough time to plan for a contingency and act upon the risk" [3]. "If the team cannot be reasonably assured that the risk can be detected because it is, in a sense, sneaky or has subtle symptoms, the detection number must be assigned as a 10 at initial planning". If the risk is, as Pritchard [10] noted, "like a freight train that can be heard for miles," then the detection value will be smaller because the team has adequate time to plan a workaround or mitigate the risk once the symptoms are identified. The detection value helps to further rank risks in order to deal with those that require attention immediately [3].

The PT-FMEA should be introduced during a team planning meeting, utilizing the template form modified as needed for the specific project.

\section{SIMPRO-Q Web-Based Educational Tool}

SIMPRO-Q or Quality Management System Role Play Simulation educational tool was developed in 1989 [13] at the Technical University of Kosice, Slovakia.

The role-playing simulation basis is a team-based experimenting with quality management system (QMS) prepared in advance. The team includes individuals that are being educated in quality management at HEI or real life managers of an organization. 
The nature, objectives and stages of SIMPRO-Q have been maintained also in PT-SIMPRO-Q, and only the quality management processes were changed so that they comply with ISO 10006:2003 and with the risk management processes as given in ISO 31000:2010.

The stages include:

- Strategic process;

- Resource-related processes and personnel-related processes;

- Interdependency-related processes, scope-related processes, time-related processes, cost-related processes, communication-related processes, riskrelated processes, purchase-related processes;

- Improvement-related processes, processes of measurement and analysis, and processes of continual improvement.

\section{Simulation Role-Play: Quality MANAGEMENT IN THE PRODUCTION RELOCATION PROJECT}

The basis of the production relocation simulation and modeling is to arrive at the prediction of future tasks of the project quality management, using role-plays.

Further the role-play aims at identification, modeling, analyzing and evaluation of risks anticipated in advance and behavior of personnel, designed so that they are manageable within a successful relocation of a production.

Once the play has been prepared, the facilitator explains to the players that they are going to take on roles of partial design team managers and that their task would be to establish the project quality management system matching a previously selected model. Next, the players will be guided by the facilitator, passing individual simulation role-play stages whilst performing assigned tasks. They may help the process by discussing some issues with the facilitator, through mutual discussions or by studying online documents and other complementary materials. In this way, the preselected educational goals are achieved together with the necessary documents.

Production relocation sub-processes are illustrated in Fig. 1.

A project risk is defined as "an uncertain event or condition that, if it occurs, has a positive or negative effect on a project's objectives" [14].

PT-FMEA is a living document created and then updated throughout the project stages.In doing the analysis, the system behavior is evaluated for every potential failure mode of every system component.If these unacceptable failure effects occur, design changes are made to mitigate those effects. The criticality part of the analysis prioritizes the failures for corrective action based on the probability of the item's failure mode and the severity of its effects.

It uses a scale of 1 to 10 to rank the probability of the failure mode occurrence, the severity of its failure effect and the probability of the failure being detected. These rankings are then multiplied to give the Risk Priority Number (RPN). Failure modes having a high RPN are assumed to be more important and given a higher priority than those having a lower RPN [15]. An example of filledout form for analyzing and evaluating risks using the PTFMEA method is presented in Tab. 1. Four of the 88 potential failure mode with the highest RPN for each monitored element (Machine, Man, Environment, Material), was chosen as an example to illustrate the specific relocated production.

To meet the purpose of role-plays in respect to the PTSIMPRO-Q, the following phases can be formulated:

$1^{\text {st }}$ phase: Presentation of project organization

- familiarization with the project organization; (replication of the organizational structure, the replication process, replication of work management process);

- finding the right places for the right people in the project;

- risk identification and modeling;

- acceptance of position in a project organization.

$2^{\text {nd }}$ phase: Experimentation with the processes of the project QMS

- selection from processes randomly distributed between players;

- acceptance of assigned processes;

- taking responsibility for the processes;

- risk analysis.

$3^{\text {rd }}$ phase: Experimenting with project QMS process input /output information (documents)

- selecting from randomly distributed output documents;

- acceptance from distributed output documents;

- formulation of the comparative effective value;

- risk evaluation and decision making.

$4^{\text {th }}$ phase: Documentation of a project QMS

- improved descriptions of managerial tasks;

- defined and modeled processes of the project QMS;

- responsibility and competence matrices in the project QMS;

- documented PT-FMEA plan.

$5^{\text {th }}$ phase: Experimenting with the functioning of the project QMS

- testing of the modeled situation in a project (falling behind schedule, etc.);

- analysis of reasons, evaluation of the definition of responsibilities;

- ability to alleviate the project risks;

- improvements and preventive actions taken.

Results of the role-play are pre-defined and progressively filled-in reports on gradual meeting partial objectives of the project.

Final solutions are attained through consensus of the role-players, using partial indicators of the project success. 
PAPER

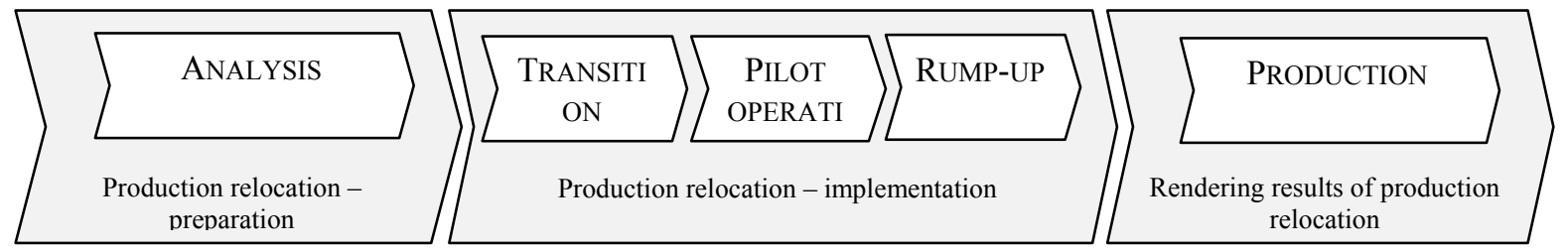

Figure 1. Production relocation sub-processes (adopted from [4])

TABLE I. $\quad$ A PART OF THE PT-FMEA FORM

\begin{tabular}{|c|c|c|c|c|c|c|c|c|c|c|c|c|c|c|c|c|c|c|c|c|c|c|}
\hline \multirow{2}{*}{$\mathbf{N}^{\circ}$} & \multirow{2}{*}{ 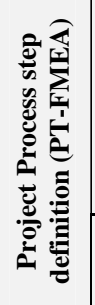 } & \multicolumn{2}{|c|}{$\begin{array}{l}\text { Potential } \\
\text { Failure }\end{array}$} & \multirow{2}{*}{ 密 } & \multirow{2}{*}{ 总 } & \multirow{2}{*}{ 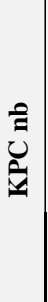 } & \multirow{2}{*}{ 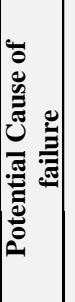 } & \multirow{2}{*}{ 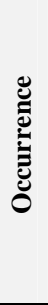 } & \multirow{2}{*}{ 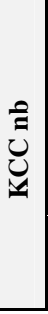 } & \multicolumn{2}{|c|}{$\begin{array}{l}\text { Project process } \\
\text { controls } \\
\text { (PT-FMEA) }\end{array}$} & \multirow{2}{*}{ ص̃ } & \multirow{2}{*}{ z } & \multicolumn{2}{|c|}{$\begin{array}{c}\text { Recommended } \\
\text { Corrective Actions }\end{array}$} & \multirow{2}{*}{ 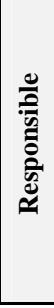 } & \multirow{2}{*}{ 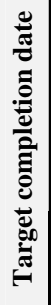 } & \multirow{2}{*}{ 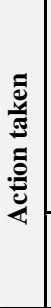 } & \multicolumn{4}{|c|}{$\begin{array}{l}\text { Forecasted } \\
\text { new RPN }\end{array}$} \\
\hline & & Mode & Effect & & & & & & & Prevention & $\begin{array}{c}\text { Detec- } \\
\text { tion }\end{array}$ & & & $\mathbf{N}^{\circ}$ & Description & & & & $\mathrm{s}$ & 0 & D & RPN \\
\hline \multicolumn{23}{|c|}{ 1. Machine } \\
\hline 1.1 & 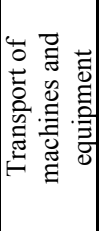 & 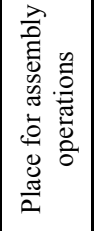 & 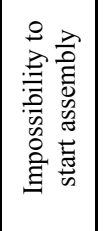 & 10 & & & 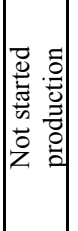 & 5 & & $\begin{array}{l}\text { Developers } \\
\text { timing }\end{array}$ & & 10 & 500 & & $\begin{array}{c}\text { Monitoring of } \\
\text { developers }\end{array}$ & 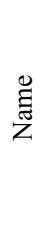 & 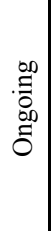 & 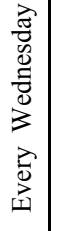 & 5 & 1 & 5 & 25 \\
\hline \multicolumn{23}{|c|}{ 2. Man } \\
\hline 2.1 & 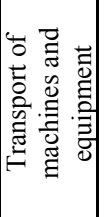 & 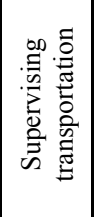 & 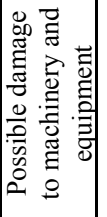 & 10 & & & 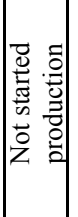 & 5 & & $\begin{array}{l}\text { Process of } \\
\text { costs control } \\
\text { and } \\
\text { transportation }\end{array}$ & & 5 & 250 & & $\begin{array}{l}\text { Defining the } \\
\text { responsibility } \\
\text { for oversight of } \\
\text { transportation }\end{array}$ & 壱 & 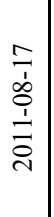 & 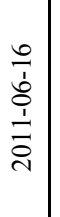 & 5 & 1 & 1 & 5 \\
\hline \multicolumn{23}{|c|}{ 3. Environment } \\
\hline 3.3 & 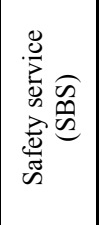 & 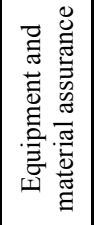 & 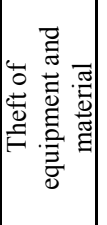 & 10 & & & 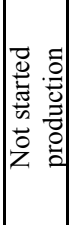 & 5 & & $\begin{array}{l}\text { Insurance } \\
\text { agreement } \\
\text { with SBS }\end{array}$ & & 10 & 500 & & $\begin{array}{l}\text { Fill in the } \\
\text { timing list }\end{array}$ & 节 & 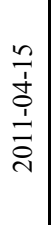 & 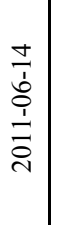 & 5 & 1 & 5 & 25 \\
\hline \multicolumn{23}{|c|}{ 4. Material } \\
\hline 4.4 & 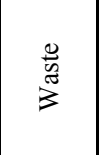 & 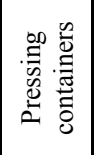 & 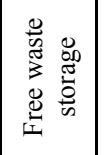 & 5 & & & 可 & 5 & & $\begin{array}{l}\text { Ensuring } \\
\text { waste } \\
\text { containers and } \\
\text { their location }\end{array}$ & & 5 & 125 & & $\begin{array}{c}\text { Agree } \\
\text { containers } \\
\text { reservation } \\
\text { with VODS }\end{array}$ & 营 & 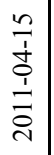 & 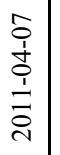 & 1 & 1 & 1 & 1 \\
\hline
\end{tabular}

$\mathrm{S}$ - Severity (Impact). It is ranked according to seriousness of the failure mode effect on the project objectives if the risk event occurs.

$\mathrm{O}$-Occurrence (Likelihood). It is ranked according to the failure probability, which represents the relative number of failures anticipated during the project life of the item.

$\mathrm{D}$ - Detectability (Detection). It is the ability to detect the risk event with enough time to plan for a contingency and act upon the risk.

KPC - Key Product Characteristics

KCC - Key Control Characteristics

$\mathrm{RPN}$ - Risk Priority Number. The RPN index is determined as the product of severity, occurrence and detection indexes. $\mathrm{RPN}=\mathrm{S} * \mathrm{O} * \mathrm{D}$

As the simulated project moves on, the team continuously updates the PT-FMEA and checks off the completion status of actions for mitigation[16]. The quality management role-play benefits are pedagogical, project related and/or diagnostic.

\section{PT-SIMPRO-Q EDUCATIONAL OBJECTIVES}

The overall educational goal of the PT-SIMPRO-Q method is to deepen the knowledge, to improve the skills and foresight of engineers and managers involved in relocating productions, and to educate them in designing and implementing the project quality management system by mitigating risks, so that profitability of the organization would increase.

Specific partial objectives of education and training in relocation productions into similar environment due to changes in processes and products are: 
1) To learn to foresee and mitigate the production relocation risks.

- To know how to identify and model risks accompanying projects of relocating productions and production processes.

- To know how to analyze and evaluate the production process relocating project risks.

- To learn how to recognize differences in the entrepreneurial, working and cultural environments

- To learn how to mitigate project risks.

- To learn to identify economical effectiveness of the project.

2) To learn to design and implement the project quality management system

- To be able to analyze current status of production of the organization to be relocated.

- To know how to analyze the risks from the point of the project quality management system needs using PT-FMEA.

3) To learn the principles of project quality management system and of the production structure.

- To be able to design strategy, policy and objectives of project quality.

- To be able to decide on responsibilities and competences within the project quality management system that is based on information flow regarding quality, safety, environment, efficiency and economical effectiveness of the production to be relocated.

- To be able to decide what input information are vital for project quality management system processes.

4) To learn to develop the project quality management system documentation (project quality policy, documented phases of the project, quality manual, etc.).

\section{DISCUSSION}

Up to now, our experience related to the application of SIMPRO-Q to quality management system implementation in about 20 industrial organizations, about 90 small health care units, and on HEI. In all these cases it has been recognized that the system has a great predictive power. At present, we are applying the PT-SIMPRO-Q for ensuring the quality of a production relocation project. The level of competency of the role-players (employees) regarding quality management in projects and risk management was: knowledge of relevant processes and related standards, experience in team work oriented to production improvement within the company. The simulation was carried out by the core team ( 8 managers) and extended team (12 managers). The role-play lasted for 16 hours. The first stage lasted about 2 hours, the $2^{\text {nd }}$ lasted 4 hours, the $3^{\text {rd }}$ lasted 4 hours, the $4^{\text {th }}$ lasted 8 hours and the $5^{\text {th }}$ lasted 4 hours. The participants were enthusiastic about the simulation process and the following subjects were discussed:

- Ownership of quality management processes in the project.

- Documentation of inputs and outputs of quality management processes in the project.
- Interactions in quality management processes in the project.

\section{CONCLUSIONS}

Though there are number of reasons leading to relocation of a production the core reason is usually a greater profitability of the company. The paper presented web based learning method using PT-SIMPRO-Q which is role play simulation. The essence of team play is experimenting with the previously prepared project quality management system model according to ISO 10006:2003 together with processes of risk management according to ISO 31000:2010.

Participants of role play acquire new knowledge and skills before starting the production relocation as part of work based learning in the organization.

Results of the role play were project QMS documentation, PT-FMEA, and new skills of the project team. The experience of a particular use is the following:

- Participants positively evaluated the role play.

- Production relocation went smoothly and there were no serious problems with production relocation quality.

- Risk assessment was appropriate to the circumstances that actually occurred.

Further development of PT-SIMPRO-Q can be seen in extension of the process model to other factors such as Finance and Logistic.

\section{REFERENCES}

[1] Eurofound, 2006: Relocation of production and industrial relations, Retrieved on June 15, 2011, from internet http://www.eurofound.europa.eu/eiro/2005/11/study/tn0511101s.h tm

[2] H. B. Nembhard, M., S. Kao, "A forecast-based monitoring methodology for process transitions", Quality and Reliability Engineering International, Volume 17, Issue 4, pages 307-321, July/August 2001, http://dx.doi.org/10.1002/qre.403

[3] T. A. Carbone, D.D.,Tippett, "Project Risk Management Using the Project Risk FMEA", Engineering Management Journal, 2004 Vol. 16 No. 4, pg. 28.

[4] Flatworld, "Our Transition Process - Your Passage to Growth", Retrieved on 10 July, 2011, from http://www.flatworldsolutio ns.com/about-fws/transition-process.php

[5] G. Bellinger, "Modeling \& Simulation", 2004, Retrieved on 15 July, 2011, from internet http://www.systemsthinking.org/modsim/modsim.htm

[6] P. Saunders, B. Cox, The International Simulation and Gaming Yearbook, Volume 5, Research into Simulation in Education, Kogan Page, UK, 1997.

[7] J. A. Kaene, "The Virtual Approach to Quality Education", Quality Progress Vol. 31 October 1998, pp.62 - 64, USA.

[8] Zgodavova, K[ristina] (2009). Overcoming Resistance to Change Via Managerial Role-Play Simulation, Chapter 24 in DAAAM International Scientific Book 2009, pp. 223-232, B. Katalinic (Ed.), Published by DAAAM International, ISBN 978-3-90150969-8, ISSN 1726-9687, Vienna, Austria DOI: 10.2507/daaam.scibook.2009.24

[9] ISO 31000:2009 Risk management -- Principles and guidelines

[10] ISO 10006:2003 Quality management systems. Guidelines for quality management in projects

[11] J. Plura, Planovani jakosti vyrobku a procesu metodou FMEA Vyvoj a soucasnost, (In Czech), Proceedings of the International Conference Quality'98, DTO Ostrava, Czech Republic, 1998.

[12] C. L. Pritchard, "Advanced Risk-How Big is Your Crystal Ball?" Proceedings Project Management Institute Annual Seminars \& Symposium (September 2000). 
[13] K. Zgodavova, Quality Management Systems Role Play Simulation/Simulačné projektovanie systémov riadenia kvality, QProjekt Plus, 1998.

[14] Project Management Institute, "A Guide to the Project Management Body of Knowledge (PMBOK Guide)", 2000 Edition.

[15] J. B. Bowles and C. E. Peláez, "Fuzzy logic prioritization of failures in a system failure mode, effects and criticality analysis", Journal of Reliability Engineering and System Safety, 1995, vol. 50, pp. 203-213. http://dx.doi.org/10.1016/0951-8320(95)00068-D

[16] A. Buthmann, "Use a Modified FMEA to Mitigate Project Risks" Retrieved on 15 June, 2011 from http://isixsigma.com/index.php?option=com_k2\&view=item\&id= 1106:use-a-modified-fmea-to-mitigate-project-risks\&Itemid=203.

\section{AUTHORS}

L. Legyel is senior quality manager with the Faurecia Leather Kosice s.r.o., Slovakia, and external PhD student with the VSB Technical University of Ostrava, Czech Republic (e-mail: lengyel.lubomir@gmail.com).
K. Zgodavova, was vice-rector with the Alexander Dubcek University of Trencin, Slovakia. She is now full professor of the Technical University of Kosice and guarantee of Integrated Management and Quality Engineering study programs, Slovakia(e-mail: kristina.zgodavova@tuke.sk).

P. Bober is with the Technical University of Kosice, Slovakia. He received $\mathrm{PhD}$ degree at the Faculty of Electrical Engineering and Informatics, Technical University of Kosice, Slovakia.

This work was supported by Ministry of Education, Science, Research and Sport of Slovak Republic KEGA Project 009TnUAD-4/2011: Creative Laboratory Education at Technical Faculties (CRELABTE).

This paper is an extended and updated version of the author's paper "Modeling and Simulation of Relocation of a Production in SIMPRO-Q Web Based Educational Environment", presented at the International Conference ICL'2011 \&Virtual University'2011, held in September 2011 at Piestany, in Slovakia. Submitted, 18 November 2011. Published as resubmitted by the authors on 27 February 2012 